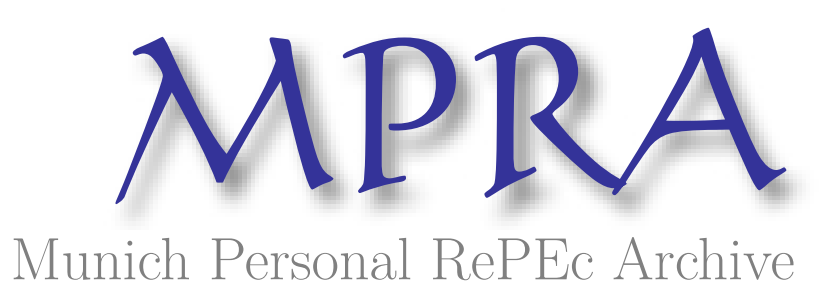

\title{
An Evaluation of the Revenue side as a source of scal consolidation in high debt economies
}

Banerjee, Ritwik

Aarhus University

7 April 2012

Online at https://mpra.ub.uni-muenchen.de/37956/

MPRA Paper No. 37956, posted 09 Apr 2012 17:58 UTC 


\title{
An Evaluation of the Revenue side as a source of fiscal consolidation in high debt economies
}

\begin{abstract}
Ritwik Banerjee*
Aarhus University, Denmark

Abstract

Unsustainable levels of debt for some European economies is causing enorghous strain in the Euro area. How to tide over the debt crisis seems to be the most important objective the European policy makers are currently facing. We use a dynamic general equilibrium closed economy model to compute the dynamic Laffer Curves for Portugal, Ireland, Greece and Spain for different class of taxes. We conclude that there exists scope for considerable revenue generation by raising certain class of taxes. Thus revenae generation, along with fiscal consolidation holds key for debt reduction.
\end{abstract}

\footnotetext{
*Email: rbanerjee@econ.au.dk; Address: Bartholins Alle 10, School of Economics and Business, Aarhus University, Aarhus C 8000, Denmark.
} 


\section{Introduction}

As Greece was aided by IMF and EU with a massive bailout package in June 2011, conditioned on some stringent austerity measures, tension mounted on the streets of Athens. The lenders however sought ever greater interest for Greek debt and as credit rating agencies downgraded the credit rating for Greece in quick succession, a sovereign default seemed inevitable. In November 2011 however European leaders got the banks to take a 50 per cent loss on the face value of Greek debt. This measure is set to bring modest success as Greek public debt is projected to reduce to 120 per cent of GDP by 2020. Presently the policy makers of the beleaguered economy is pushing through further painful structural reforms in order to secure a second bail out from the European Union members. Despite staving off immediate crisis, the critical question that the policy makers face is how to reduce debt in a successful and sustainable way in the longer horizon for the four high debt European economies - Portugal, Ireland, Greece and Spain.

The conventional wisdom for fiscal consolidation is expenditure cuts. In this paper I argue that in addition to the received wisdom of fiscal consolidation through expenditure cut 8 , revenue generation through an increase in certain class of tax rates should also be considered. I computethe dynamic Laffer curves for the four economies by calibrating a flex-price Cass-Koopmans style model and show that there exists some room for tax maneuverability. The rest of the paper is organized as follows. Section 2 discusses major lessons from successful debt reductions in the past. Section 3 talks about the present debt crisis and how it evolved through the decade. Section 4 lays out the model and the calibration details and section 5 discusses the main results.

\section{Lessons from past suceessful debt reductions}

Historically successful debt reduction strategies as analyzed by Nickel et al. (2010) can be characterized into two main classes. One, robust macroeconomic environments help economies "grow out of debt" in the long run and two, the economies work towards maintaining primary budget surpluses through decisive and lasting fiscal consolidation efforts. This long term fiscal consolidation efforts focus on decreasing government expenditure through cuts on welfare benefits and public wage spending. They argue that the past experiences of successful debt reduction (e.g. in Denmark public debt was reduced from 80 per cent in 1994 to 26.8 per cent in 2007; Belgium and Finland too had similar experiences) suggest that expenditure based methods have been more successful than revenue based methods so far as reducing debt is concerned. Fiscal adjustments through spending cuts on transfers and government wage bill was also favored by Alesina and Perotti (1996) to that by tax increases. This finding is subsequently reconfirmed by Alesina and Ardagna (2009) with data from 1970-2007. 
However one must note that it is often empirically impossible to clearly identify the underlying policy changes as most expenditure cut induced fiscal consolidation has been accompanied by structural reforms. The structural reforms often lead to an improvement in employment and in turn in revenue and expenditure scenario since higher employment results in higher tax revenue and lower welfare expenditure. Also in the light of recent instances it is amply clear that there is an enormous political cost associated with forced government employment reduction and wage cut. It is widely believed today that given the enormity and complexity of the current problem, any sustainable fiscal consolidation will require a multi-pronged strategy.

To understand why a range of strategies should be employed in order to bring down public debt to sustainable levels, let us decompose public debt conceptually into three main structural component(s - primary balance, real growth differentials and interest payments (Cottarelli et al. (2010)). An increase in the growth rate of real GDP increases the revenue accrual to the government by increasing the tax receipt. This leads to a decrease in welfare expenditures too, thus having a direct bearing on the debt size. As servicing debt stock expend considerable part of the resources, interest rate movements have considerable impact on the debt size. However as Cafiso (2012) shows the largest component of debt-GDP ratio is mainly driven by the primary balance. He shows for EU- $15^{1}$ countries increase in primary balance accounts for $37 \%$ of the share of debt GDP ratio. This share is as high as $79 \%$ in Spain, suggesting that any credible set of policies which intends to address public debt will directly need to tackle primary balance. This in turn will make a considerable impact on the two previous components through deficit-growth linkage and debt stock reduction.

The question then boils down to the following - What are the best ways of bringing down the primary balance. First, debt restructuring will have to play an important role inspite of repeated claims by the President of European Central Bank that public debt wilnotbe written off under any circumstances. Especially, as noted by Cabral (2010), for Portugal, Ireland, Greece and Spain since Gross external debt position is very high which implies that interest payment for a majority of this debt is paid abroad and a tax on these interest payments accrue to governments abroad. So any attempt towards fiscal consolidation without incorporating debt restructure of some form or the other is likely to aggravate problem. Second, as has been widely noted in the literature it is important to reduce public expenditure which all these major debt ridden economies have started working on. But as is evident that this process of reducing public expenditure will be very painful not only interns of employment but also in terms of long term growth. Finally, the other option which has not been adequately explored is the possibility of raising tax revenue in these economies, through an increase in tax rate. Our objective in this paper is to explore in detail whether pursuing such a strategy makes sense in the current context.

\footnotetext{
${ }^{1}$ EU-15 countries include Austria, Belgium, Denmark, Finland, France, Germany, Greece, Ireland, Italy, Luxembourg, Netherlands, Portugal, Spain, Sweden, United Kingdom
} 


\section{Present Paradigm}

The rise in debt-GDP ratio began from 2007 though its major escalation started in 2008. This was a global phenomenon. World leaders pledged collective action through fiscal stimulus to prevent the downward spiral of the world economy and high unemployment meant welfare expenditures were on the rise. Figure 1 shows how Greece and Portugal, whose debt-GDP ratio $^{2}$ was already at unsustainable levels, escalated by 40 percentage points and 20 percentage points respectively in the period 2008-10. Spain and Ireland suffered similar fate as a hitherto stable debt-GDP ratio saw a rapid rise - over 30 percentage points in the case of Ireland in the same period. The situation has come to such a passe today that for successful fiscal consolidation of EU, it is now believed that the required average total debt reduction per country will have to be to the tune of 37 percentage points of GDP.

The strategy of "growing out of debt" is clearly not feasible as the fundamentals of the economies are severely flawed. While Spain and Ireland have barely managed to maintain a positive growth in the last five quarters ${ }^{3}$ at $0.1 \%$ and $0.12 \%$ respectively, Portugal and Greece have been growing negafively at $-0.6 \%$ and $-1.48 \%$ respectively, during the same period. Thus they have taken recourse to improving the primary balance through painful spending cuts under the close monitoring of ECB, European Commission and the IMF, in order to allay market apprehensions of a possible bankruptcy. For example, the new Greek government has agreed to cut spending by 1.5\% of GDP in order to obtain a substantial debt write-off. Other painfulprescriptions for making structural changes like reducing the public sector employees by 150,000 , pushing ninimum wage from $\$ 1000$ a month to $\$ 750$ a month to enhance competitiveness of Greek workers etc. are underactive consideration. The two year long austerity drive, coupled with a $19 \%$ unemployment and a deep recession is causing enormous social tensions in the country.

Our paper does not concern its lf with investigating the reasons for such sharp increase in debt-GDP ratio, nonetheless a look at Table, 3 may be instructive. The tax-GDP ratio has been falling for all of the above countries over the last decade. In the pre-crisis period, except Spain, all the countries have suffered tax revenue drop, which in the case of Greece has been rather consistent. The second panel of the same graph tells a different story. Government expenditure has been growing at steady pace throughout the decade. A closer look at the 2008-09 shows that while tax revenue fell in all countries, government expenditure continued to grow phenomenally. This was clearly the result of the expansionary stance taken by the governments and this in turn blew the lid off the debt-GDP ratio. Note that in a crisis year, a drop in tax-GDP ratio is not surprising but what we see is a consistent fall throughout the decade coupled with a decrease in the growth rate of tax revenue. This brings us to the question we are interested in. Does tax rate increase merit a relook so far as debt-reduction strategies are considered, especially given that tax

\footnotetext{
${ }^{2}$ We use central government debt as reported by OECD Stat. as a measure of debt in this case

${ }^{3}$ Quarter 1, 2011 to Quarter 1, 2012. Source: IFS, IMF
} 
rate in Europe has been monotonically falling through the decade? Even in these economies with rapidly rising public expenditure and falling tax-GDP ratio, tax rates have consistently decreased. ${ }^{4}$

Laffer curve is one instrument through which we can locate an economy in a tax rate-tax revenue panel. We can assess whether the economy is on the left of the peak of the Laffer Curve, thus leaving us with a possibility of increase in tax revenue with a ceteris paribus increase in tax rate. Note that an increase in tax rate tends to adversely affect growth and thereby overall tax revenue. Thus we compute the dynamic steady state Laffer curves which reflect the locus of tax revenue after controlling for the loss in revenue due to the adverse impact growth. Though Corsetti and Muller (2012) conjecture that "there is equally little evidence to suggest that fiscal policy is on the wrong side of the Laffer curve", dynamic laffer curves for debt ridden European economies have not been computed before. We solve a simple, closed dynamic model and compute this. Then we precisely locate four debt ridden economies, Greece, Portugal, Ireland and Spain in their corresponding dynaní Laffer Curves for different taxes and draw policy conclusions from there.

\section{Model and Calibration}

We solve a standard dynamic closed economy model to compute the steady state values of consumption, capital and labor supply. In our simple set up the consumers maximize their utility with respect to consumption and leisure, firms produce output using a Cobb Douglas technology and governments run a balanced budget ${ }^{5}$ where $^{-}$ the tax revenue that it earns is used for lump sum transfer to the consumers and for providing with public goods which in turn enter the utility function of the consumers.

Formally the model can be written as follows -

$$
\max _{c, l} \int_{0}^{\infty}\left(\ln c-k l^{1+\frac{1}{\psi}}++\xi G^{1-n}\right) e^{-\rho t} d t
$$

where $c, l, a$ are period consumption, leisure and assets; $\tau_{c}, \tau_{r}, \tau_{w}, T, w, r$ are consumption tax, capital tax, income tax, lump sum tax, wage and rental rate respectively; the constraint denotes the asset accumulation equation; the

\footnotetext{
${ }^{4}$ Our calculation shows that a simple measure of Average Personal Income Tax rate, obtained from an average of tax rate for Single parent without children, One-earner married couple with two children and two-earner married couple with two children, has steadily decreased. The decrease ranges from 1.4 percentage points in Greece to 1.7 percentage points in Ireland.

${ }^{5}$ In this case government running a balanced budget can be thought of as an infinite period present value budget balanced, though explicit characterization makes it difficult to solve. Also that brings in an additional element of debt dynamics. That may be a future work though where the debt position of each of these countries are compared against the steady state debt levels obtained through numerical solution of a dynamic model.
} 
parameters $\psi, \rho, \kappa$ and $\xi$ denote the Frisch elasticity of labor supply, time preference rate, weight on disutility of labor and weight on government consumption. The model crucially rests on the assumption that government consumption $G$, enter the household utility separably from consumption and leisure ${ }^{6}$. Furthermore the preference has a constant Frisch elasticity of labor supply and the intertemporal elasticity of substitution is unity. Our utility function is a particular form of the general Constant Frisch Elasticity (CFE) utility function which appears in Trabandt and Uhlig (2010). It is this specification which yields unit intertemporal elasticity of substitution.

The standard first order conditions give us the Euler equation

$$
\dot{c}=c\left(\left(1-\tau_{p}\right) r-\rho\right)
$$

The firms maximize their profit and markets clear. We can then define the competitive equilibrium as the set of variables $c, k, l, r, w$ which solve the following equations -

I analytically derive the steady state values $l_{s s}, k_{s s}, c_{s s}$ and numerically verify them. The steady state revenue calculation follows easily and is given by -

$$
R_{s S}=\tau_{w} w l_{s s}+\tau_{r} r k_{s s}+\tau_{c} c_{s s}
$$

A detailed solution of the model is given in the Appendix.

The model is calibrated to the data of the four economies we are interested in - Portugal, Ireland, Greece and Spain. European Union -14 has also been included in order that it serves as a reference point for the results we obtain from calibrating the individual economies. The calibrated values of consumption, labor and capital taxes are obtained fromTrabandt and Uhlig (2010). Given the complexities involved in calibration of various country parameters, one

\footnotetext{
${ }^{6}$ Christiano and Eichenbaum (1992) was one of the first papers to use this preference. It can be interpreted as the entire government expenditure being used to produce public goods which in turn enter the preferences of the individuals.
} 
litmus test for whether the parametrization can be thought of as reasonable, is if steady state solution for optimal labor hours worked is similar to prior studies. Numerical solutions of several studies show that in EU-14 $4^{7}$ the optimal labor hours chosen by the consumers is 0.25 . Our set of parameters for preference and tax rates yield a very close value - 0.245 . Furthermore we use two values of the constant Frisch elasticity of labor supply with $\psi=1$ and $\psi=3$ in order to show robustness of our results ${ }^{8}$. Finally the steady state values are analytically computed and then numerically verified using the relaxation algorithm developed by Trimborn et al. (2008).

The relation algorithm is an efficient method of determining the transition process in growth models numerically. It can be used to compute a wide class of general equilibrium models. The transition process, which is a solution to a differential equation, is arrived at by using a trial solution which satisfies neither the slope condition nor the boundary conditions. Subsequently the corresponding error function is obtained and its first derivative is computed to improve the trial solution. At each point of iteration, the correction takes into account the deviation from the correct slope condition and also solves the static equation(s), untita predetermined threshold level of error is reached through a Newton type iteration.

Table 1 gives us the calibrated values of the tax rates of these economies in 2007 while Table 2 gives us the parameter values.

\begin{tabular}{|c|c|c|c|}
\hline & Labor Income Tax Rate & Capital Income Tax Rate & Consumption Tax rate \\
\hline EU-14 & 41.3 & 34.4 & 16.9 \\
\hline Portugal & 34.4 & 27.6 & 21.5 \\
\hline Ireland & & 22.5 & 25.6 \\
\hline Greece & 40.3 & 14.5 & 21.5 \\
\hline Spain & 37.4 & 36.2 & 14.7 \\
\hline
\end{tabular}

\footnotetext{
${ }^{7}$ EU-14 comprises of Austria, Belgium, Denmark, Finland, France, Germany, Ireland, Italy, Netherlands, Portugal, Spain, Sweden, United Kingdom

${ }^{8}$ Our graphical analysis shows,$\psi=3$ is close to the threshold choice of the Frisch elasticity parameter which makes revenue neutral with respect to tax increases. It is important to note however thatTrabandt and Uhlig (2010) mentions $\psi=1$ as their "preferred benchmark calibration".
} 
Table 2: Parameter values

\begin{tabular}{ccccc}
\hline & $\alpha$ & $\delta$ & $\kappa$ & $G / y$ \\
\hline \hline EU-14 & 0.38 & 0.07 & 3.62 & 0.23 \\
\hline \hline Portugal & 0.39 & 0.10 & 3.39 & 0.23 \\
\hline \hline Ireland & 0.36 & 0.09 & 5.66 & 0.19 \\
\hline \hline Greece & 0.40 & 0.06 & 3.36 & 0.20 \\
\hline \hline Spain & 0.42 & 0.09 & 5.12 & 0.21 \\
\hline
\end{tabular}

\section{Results}

Figure 2 gives us the Dynamic Laffer curve for consumption tax. The shape of the Laffer curve is dictated by the fact that consumption can never drop to zero. So in increasing the tax rate nn the consumption has some rationale if the objective is solely how to generate surplus revenue, as the inelástic consumption will lead to an increase of tax revenue. The current consumption tax rate for each of the economies have been marked. A near constant slope implies a 10 percentage points (ppts henceforth) increase in consumption tax yields on an average a revenue increase of 15 per cent. A relatively steeper slope for Greece indicates that upto 20 per cent revenue increase can be achieved by a 10 ppts increase in consumption tax rate at the current tax levels.

Figure 3 shows the dynamic laffer curves for capital tax when the value of Frisch elasticity of labor supply is unity. Spain has the highest and Greece has the lowest capital tax rate among the four countries analyzed here . However irrespective of that itis evident from the graph that the possibility of enhancing the tax revenue by increasing the capital tax rate is limited. Infact the tax revenue sharply drops for any tax rate above 50 per cent. The average tax rate for EU-14 Itself is quite high and does not merit any increase. A caveat must be in place though the model that we calibrate does not incorporate the external sector. The result in the case of capital taxes may vary once that is incorporated as capital has a tendency to fly if adversely taxed. Having said that we note thatTrabandt and Uhlig (2010) justify their assumption of closed economy by stating that if the model is viewed in the light of ownership based taxation instead of source based taxation then fiscal policy will not have much cross border effect.

Figure 4-8 gives us the dynamic laffer curves for income tax for each of the economies. Each panel computes the laffer curve for Frisch equals one and three. Greece has the highest income tax among them at over 40 per cent. We find that while Spain and Portugal can only raise the tax revenue by 12 per cent and 12.5 per cent respectively by a 10 ppts increase in income tax rate at eh current level of taxes. The corresponding figure for Greece and Ireland is 13 
per cent and 14 per cent respectively. This suggests that there exists a possibility of a substantial increase in tax revenue through an increase in the income tax rate, particularly for Greece and Ireland. Even if such a tax increase were to take place, Irish economy will continue to be sufficiently to the left of the Laffer peak.

\section{Conclusion}

In many debt ridden countries the governments have tried to incorporate the painful process of fiscal discipline, though mostly unsuccessfully. In fact as we have seen in many cases a public debt reduction led by shedding government expenditure through employment and pay cut has resulted in enormous sodio-political tensions. The consequence of a marginal increase in income tax rate on the other hand is much less. We solve a simple dynamic model and compute the dynamic Laffer curve for capital tax, income tax and consumption tax for four highly indebted economies - Portugal, Ireland, Greece and Spain. Our analysis shows under reasonable parametrization, there exists a scope for maneuverability with tax rates for certain class of taxes. All the economies are located to the left of the Laffer peaks for the income tax and will be able to ábsorb marginal increase in tax rates with sacrificing growth rate. This will generate much needed resources to bring down the primary deficit which along with structural changes led expenditure cuts may be able bring down the debt to sustainable levels.

\section{References}

Alesina, A., Perotti, R., Jul. 1996. Fiscal adjutstments in oecd countries - composition and macroeconomic effects. IMF Working Papers 96/70, International Monetary Fund.

Alesina, A. F., Ardagna, S. Óctober 2009. Large changes in fiscal policy: Taxes versus spending. Working Paper 15438, National Bureat of Economic Research.

Cabral, R., May 2010. The pigs external debt problem. VoxEU.

Cafiso, G., January 2012. Debt developments and fiscal adjustment in the eu. Intereconomics: Review of European Economic Policy 47 (1), 61-72.

Christiano, L. J., Eichenbaum, M., June 1992. Current real-business-cycle theories and aggregate labor-market fluctuations. American Economic Review 82 (3), 430-50.

Corsetti, G., Muller, G., 2012. Has austerity gone too far? VoxEU. 
Cottarelli, C., Forni, L., Gottschalk, J., Mauro, P., Sep. 2010. Default in today's advanced economies: Unnecessary, undesirable, and unlikely. IMF Staff Position Note 2010/12, International Monetary Fund.

Nickel, C., Rother, P., Zimmermann, L., Sep. 2010. Major public debt reductions: Lessons from the past, lessons for the future. Working Paper Series 1241, European Central Bank.

Trabandt, M., Uhlig, H., 2010. How far are we from the slippery slope? the laffer curve revisited. NBER Working Papers 15343, National Bureau of Economic Research, Inc.

Trimborn, T., Koch, K.-J., Steger, T. M., June 2008. Multidimensional transitional dynamics: A simple numerical procedure. Macroeconomic Dynamics 12 (03), 301-319.

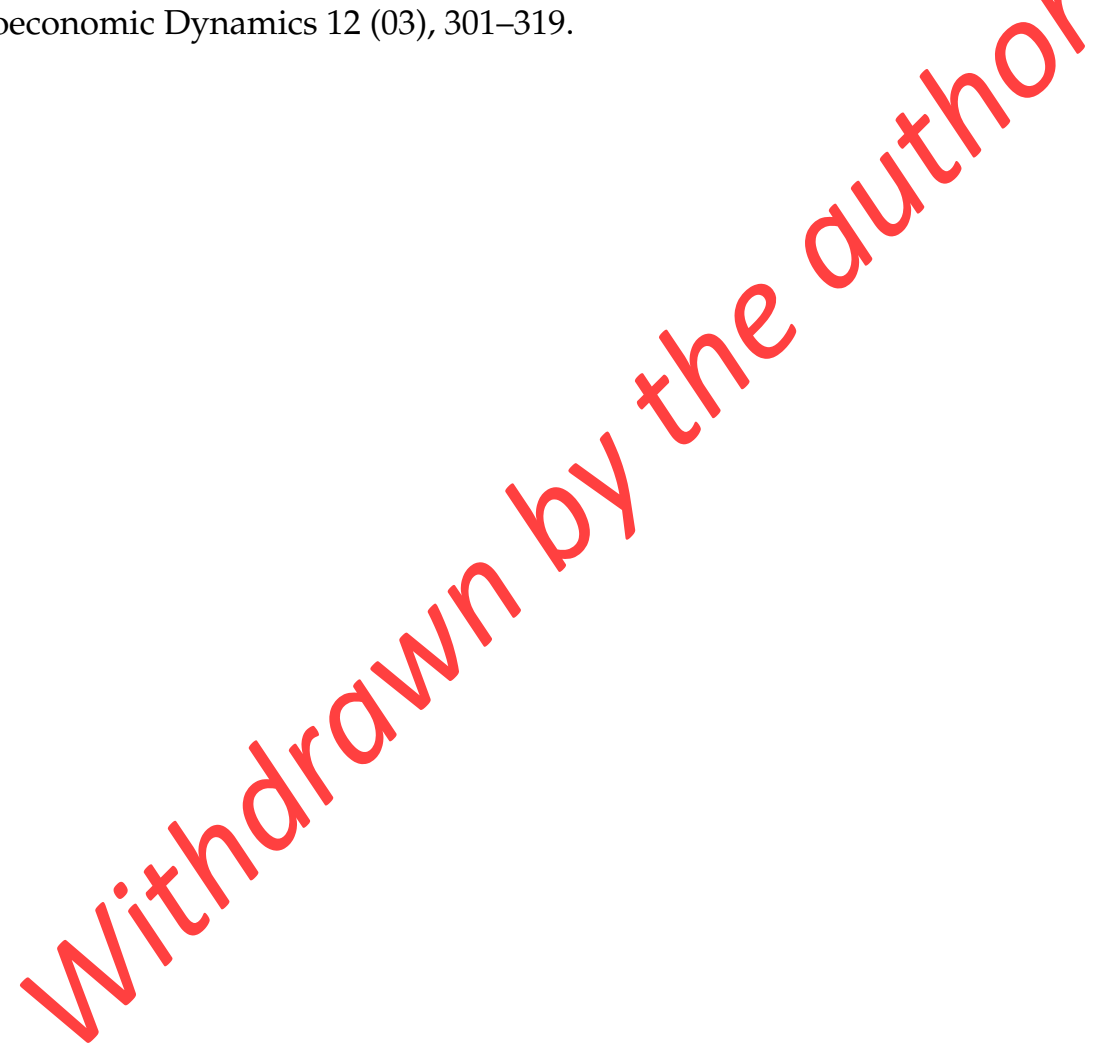


Figure 1: Central Government Debt as a Percentage of GDP

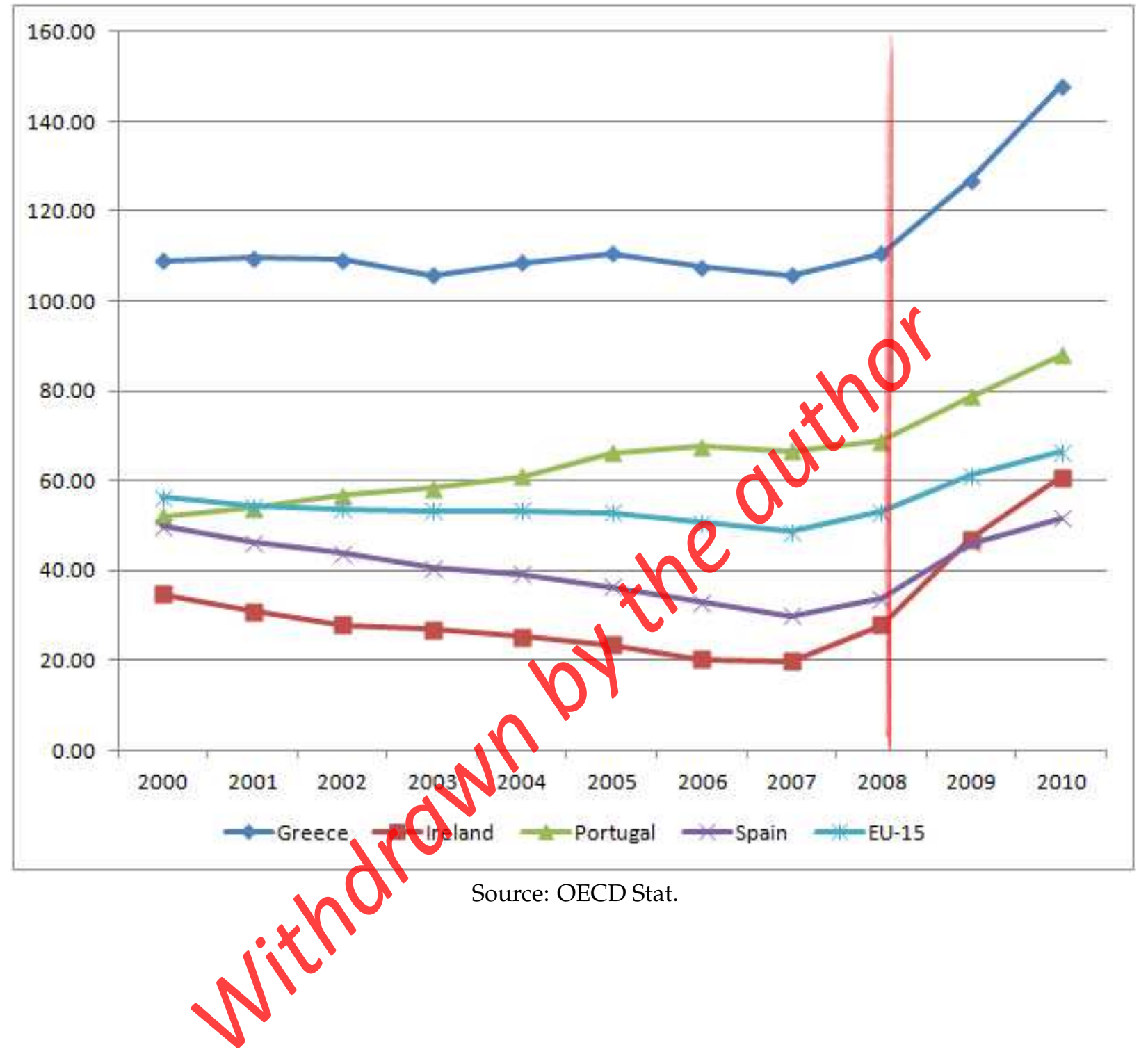


Table 3: Tax Revenue and Government Expenditure

\begin{tabular}{|c|c|c|c|c|c|c|c|c|c|c|}
\hline & \multicolumn{5}{|c|}{ Growth of Tax Revenue as a percentage of GDP } & \multicolumn{5}{|c|}{ Growth of Government Expenditure } \\
\hline & Greece & Ireland & Portugal & Spain & EU 15 & Greece & Ireland & Portugal & Spain & EU 15 \\
\hline 2001 & -3.3 & -7.3 & -0.6 & -1.2 & -2.8 & NA & 18.1 & 9.1 & 6.5 & 7.1 \\
\hline 2002 & 1.9 & -3.9 & 2.0 & 1.1 & -1.4 & NA & 12.2 & 4.0 & 7.9 & 6.1 \\
\hline 2003 & -4.6 & 1.8 & 0.7 & 0.1 & -0.5 & NA & 6.6 & 5.6 & 6.0 & 5.0 \\
\hline 2004 & -2.5 & 5.3 & -3.7 & 1.4 & 0.4 & NA & 8.1 & 6.2 & 8.8 & 4.8 \\
\hline 2005 & 2.1 & 1.7 & 2.6 & 3.2 & 2.3 & NA & 9.5 & 5.8 & 6.8 & 4.5 \\
\hline 2006 & -2.0 & 4.3 & 2.3 & 2.4 & 1.1 & NA & 10.8 & 1.4 & 8.1 & 4.2 \\
\hline 2007 & 2.0 & -2.2 & 1.9 & 1.8 & -0.2 & 12.3 & 13.8 & 5.3 & 9.3 & 10.7 \\
\hline 2008 & -1.1 & -6.1 & 0.2 & -10.5 & -2.5 & & 10.8 & 2.6 & 9.2 & 8.0 \\
\hline 2009 & -4.6 & -4.3 & -5.9 & -8.0 & -3.4 & & 1.7 & 9.1 & 7.5 & 6.1 \\
\hline 2010 & 3.0 & 0.7 & 2.2 & 3.4 & -0.5 & & 1.5 & 5.5 & -1.1 & 6.5 \\
\hline
\end{tabular}

Source: OECD Stat.

Figure 2: Dynamic Laffer Curve for Consumption Tax

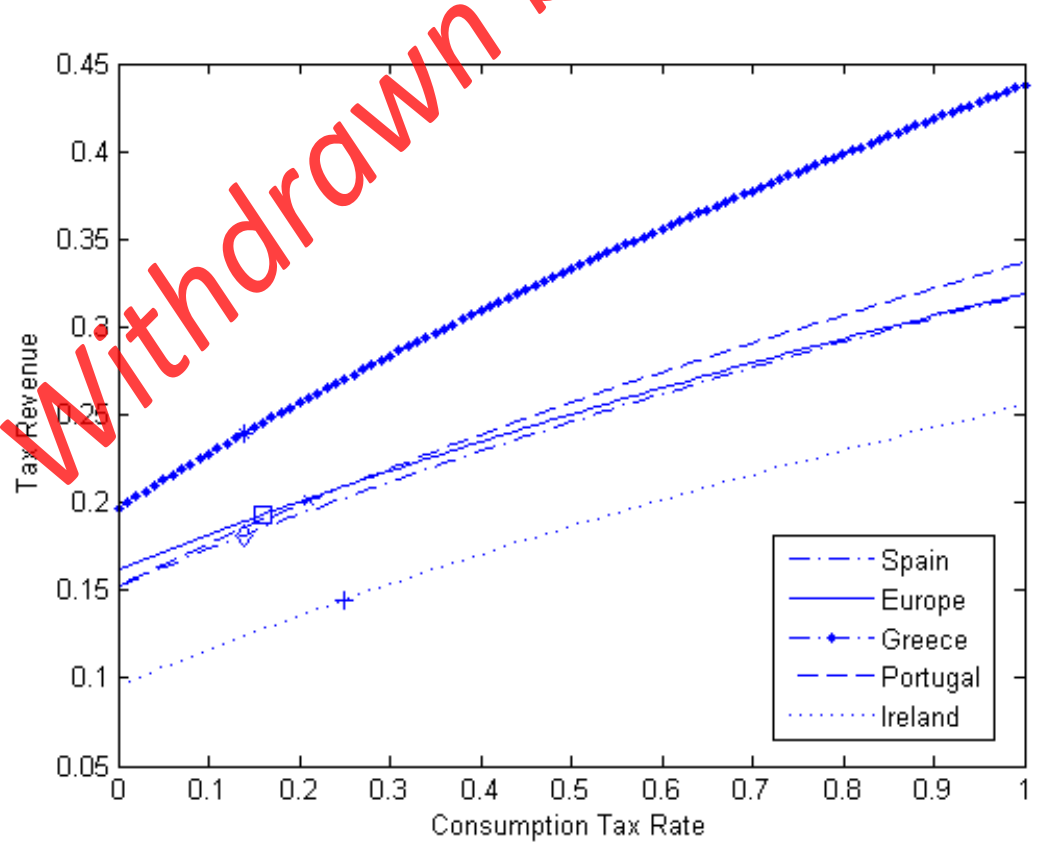


Figure 3: Dynamic Laffer Curve for Capital Tax

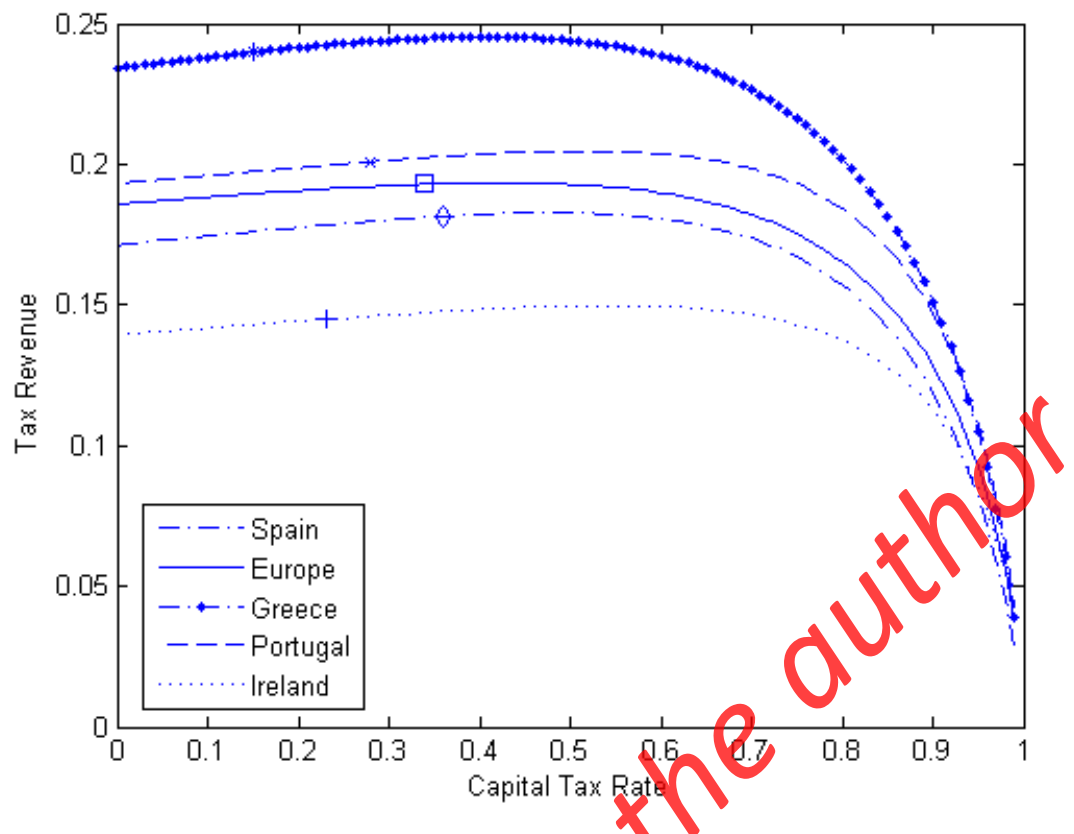

Note: Europe refers toEU-14

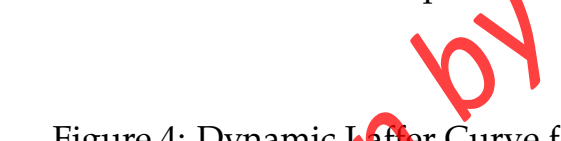

Figure 4: Dynamic Laffer Curve for Income Tax : EU-14

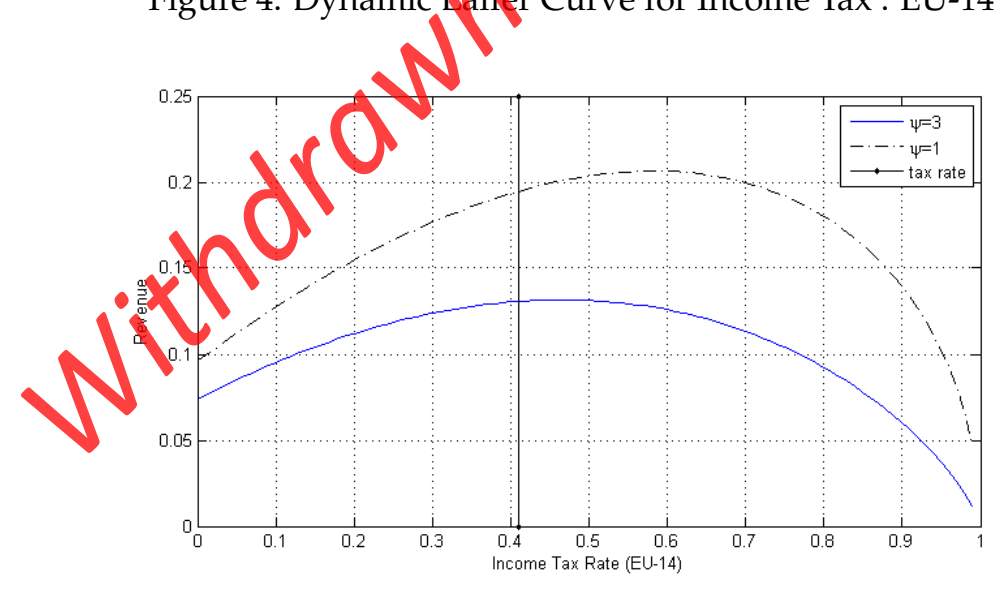


Figure 5: Dynamic Laffer Curve for Income Tax : Spain

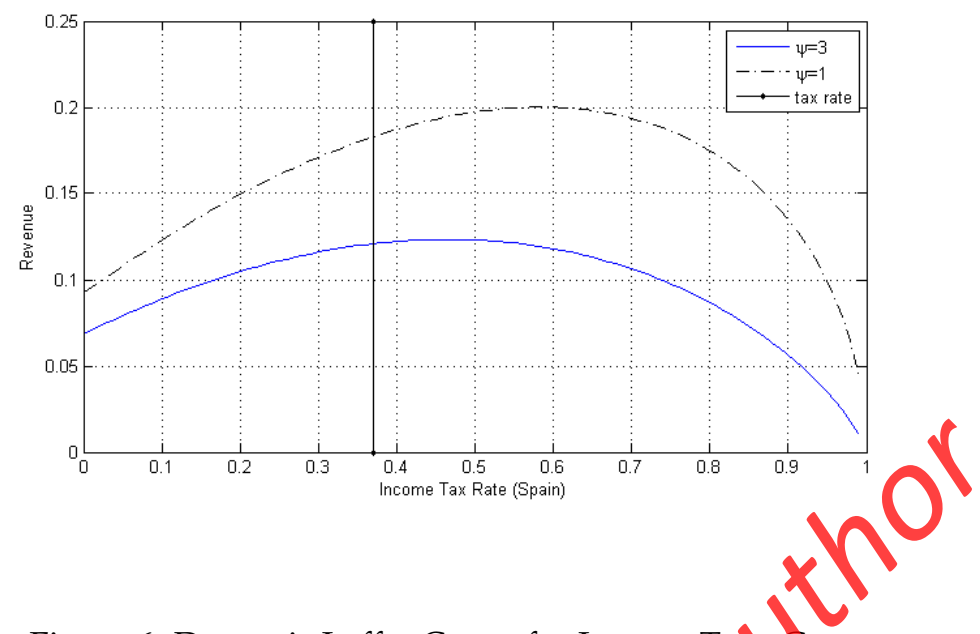

Figure 6: Dynamic Laffer Curve for Income Tax : Greece

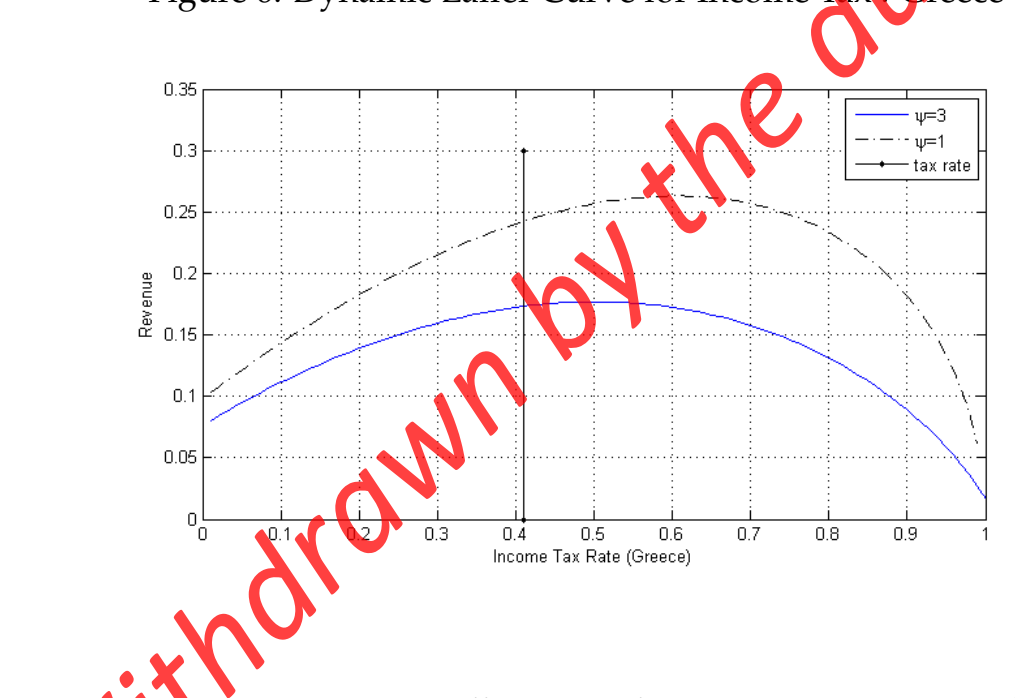

Figute 7: Dynamic Laffer Curve for Income Tax : Portugal

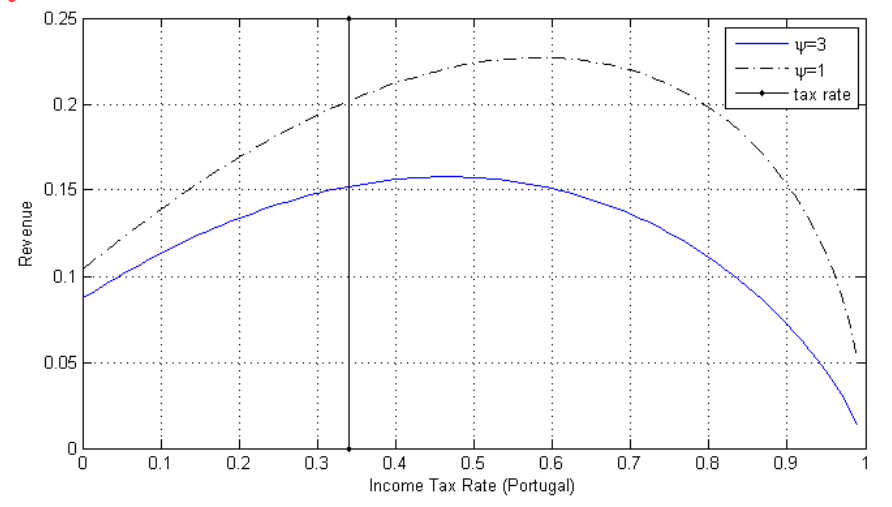


Figure 8: Dynamic Laffer Curve for Income Tax : Ireland

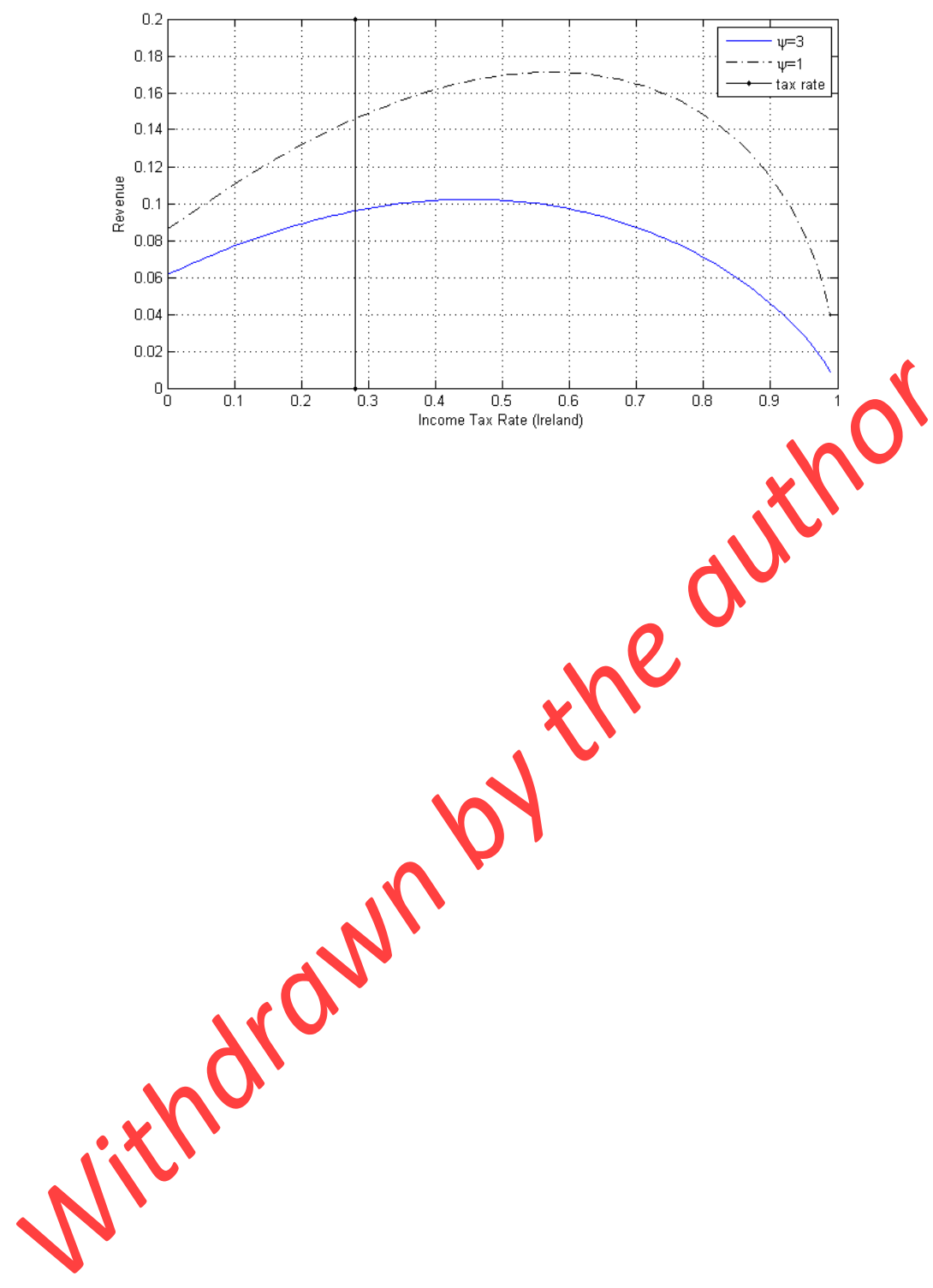




\section{Appendix}

\section{A The Model}

We model an infinite period, continuous time economy with households of unit measure, whose period utility depends on $c_{t}$, leisure $1-l_{t}$ and consumption of goods provided by the government given by $G_{t}$. The household faces an asset accumulation equation and is subjected to different taxes (given in the equation). The optimization problem is

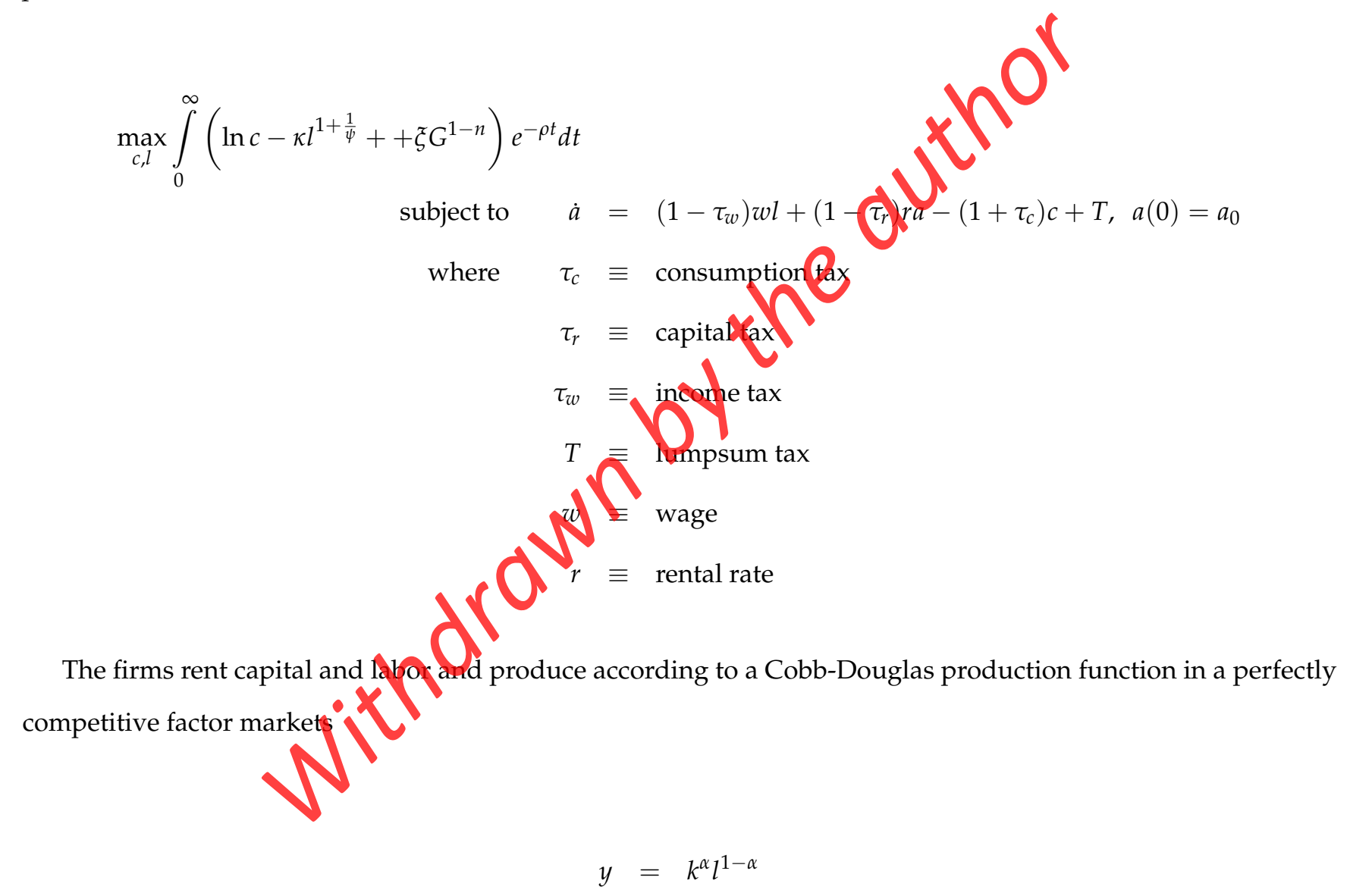

Government run a balanced budget and the budget equation is given by

$$
\tau_{w} w l+\tau_{r} r a+\tau_{c} c=T+G
$$

The continuous time Bellman equation may be formulated as follows 


$$
\begin{aligned}
\rho V(a)= & \max e^{-\rho t}\left(\log (c)-\kappa l^{1+\frac{1}{\psi}}+\xi G^{1-n}\right)+\frac{d}{d t} V(a) \\
& \text { subject to asset accumulation equation } \\
\dot{a}= & \left(1-\tau_{w}\right) w l+\left(1-\tau_{r}\right) r a-\left(1+\tau_{c}\right) c+T_{t}, a(0)=a_{0}
\end{aligned}
$$

The following are the first order conditions

$$
\begin{array}{r}
\text { with respect to } c: \frac{1}{c}=V_{a}\left(1+\tau_{c}\right) \\
\text { with respect to } l: \kappa\left(1+\frac{1}{\psi}\right) l^{\frac{1}{\psi}}=V_{a}\left(1-\tau_{w}\right. \\
\Longrightarrow l^{\frac{1}{\phi}}= \\
\text { with respect to the state variable } a: \rho V \\
\Longrightarrow V_{a}\left(\rho-\left(1-\tau_{p}\right) \kappa\right.
\end{array}
$$

Differentiating equation equation (1) with respect to and then inserting in equation (3), we obtain the Euler equation is given by

$$
\begin{aligned}
r+\delta & =\alpha k^{\alpha-1} l^{1-\alpha} \\
\text { and } w & =(1-\alpha) k^{\alpha} l^{-\alpha}
\end{aligned}
$$

Accounting identity would necessitate the following condition 


$$
\begin{aligned}
Y & =c+\dot{k}+\delta k+G \\
\dot{k} & =(1-g) y-c-\delta k
\end{aligned}
$$

We get equation (6) from the assumption that $G=g Y$.

Thus we have a complete characterization of the model given the capital market clears. The competitive equilibrium of the economy is given by the set of variables $c, k, l, r, w$ which satisfy the following equations

The steady state characterization of the economy is given by

$$
\begin{aligned}
r & =\alpha k^{\alpha-1} l^{1-\alpha}-\delta \\
w & =(1-\alpha) k^{\alpha} l^{-\alpha} \\
\dot{k} & \left.=(1-g) k^{\alpha} l^{1-\alpha}-c\right)^{\delta k} \\
\dot{c} & =c\left(\left(1-\tau_{p}\right) r-\right. \\
l^{\frac{1}{\phi}} & =\frac{w\left(1-\tau_{w}\right)}{c\left(1+\tau_{\alpha}\right)\left(1+\frac{1}{\psi}\right) \kappa}
\end{aligned}
$$

$l_{s s}=\left(\frac{\left(\rho+\left(1-\tau_{p}\right) \delta(-\alpha)\left(1-\tau_{w}\right)\right.}{\left(1+\tau_{c}\right)\left(1+\frac{1}{\psi}\right) \kappa\left[(1-g)\left(\rho+\left(1-\tau_{p}\right) \delta\right)-\delta \alpha\left(1-\tau_{p}\right)\right]}\right)^{\frac{\psi}{1+\psi}}$

$k_{s s}=\left[\frac{1}{\alpha}\left(\frac{\rho}{\left(1-\tau_{p}\right)}+\delta\right)\right]^{\frac{1}{-\alpha}}\left(\frac{\left(\rho+\left(1-\tau_{p}\right) \delta\right)(1-\alpha)\left(1-\tau_{w}\right)}{\left(1+\tau_{c}\right)\left(1+\frac{1}{\psi}\right) \kappa\left[(1-g)\left(\rho+\left(1-\tau_{p}\right) \delta\right)-\delta \alpha\left(1-\tau_{p}\right)\right]}\right)^{\frac{\psi}{1+\psi}}$

$c_{S S}=\left[(1-g) \frac{1}{\alpha}\left(\frac{\rho}{\left(1-\tau_{p}\right)}+\delta\right)-\delta\right]\left[\frac{1}{\alpha}\left(\frac{\rho}{\left(1-\tau_{p}\right)}+\delta\right)\right]^{\frac{1}{1-\alpha}}\left(\frac{\left(\rho+\left(1-\tau_{p}\right) \delta\right)(1-\alpha)\left(1-\tau_{w}\right)}{\left(1+\tau_{c}\right)\left(1+\frac{1}{\psi}\right) \kappa\left[(1-g)\left(\rho+\left(1-\tau_{p}\right) \delta\right)-\delta \alpha\left(1-\tau_{p}\right)\right]}\right)^{\frac{1}{1+}}$

The total revenue for the government is given by

$$
R_{s S}=\tau_{w} w l_{s s}+\tau_{r} r k_{s s}+\tau_{c} c_{s s}
$$

